\title{
Novitates
}

PUBLISHED BY THE AMERICAN MUSEUM OF NATURAL HISTORY CENTRAL PARK WEST AT 79TH STREET, NEW YORK, NY 10024 Number 3432, 9 pp., 1 table

February 27, 2004

\section{Family-Group Names for Termites (Isoptera)}

\author{
MICHAEL S. ENGEL ${ }^{1}$ AND KUMAR KRISHNA ${ }^{2}$
}

\begin{abstract}
Thirty-nine available family-group names are identified within the insect order Isoptera (termites). For all names the correct author, date, type genus, and combining stem are provided for the first time. This nomenclatural compilation is done to stabilize the usage of familygroup names in the Isoptera in advance of a world catalog. Several problems of priority are identified and discussed. The little understood subfamily Foraminitermitinae is diagnosed; while generally believed by many authors to be a new, unnamed subfamily, it was in fact established by Holmgren nearly a century ago. The subfamilies Syntermitinae and Sphaerotermitinae are newly proposed for the mandibulate genera of nasute termites and for Sphaerotermes, respectively. The classification of Isoptera is briefly outlined.
\end{abstract}

\section{INTRODUCTION}

It has long been recognized that the current usage of family-group names in the classification of termites (Isoptera) is not fully in accord with the rules of zoological nomenclature (ICZN, 1999). Not only has the authorship and date of many names been incorrectly stated (e.g., by Snyder, 1949) and the Principle of Coordination (ICZN, 1999: Art. 36) ignored, but in many instances more critical issues of priority have not been fol- lowed, thereby jeopardizing the stability of termite classification. In fact, the numerous errors that appear in Snyder's (1949) catalog have been perpetuated by subsequent authors, who, rather than checking the original literature and applying the rules of nomenclature, have lifted from Snyder or from other catalogs which were in turn derived from Snyder (e.g., Roonwal and Chhotani, 1989; Chhotani, 1997).

In our preparation of a revised catalog of

\footnotetext{
${ }^{1}$ Department of Ecology and Evolutionary Biology, and Division of Entomology, Natural History Museum, Snow Hall, 1460 Jayhawk Boulevard, University of Kansas, Lawrence, Kansas 66045-7523. e-mail: msengel@ku.edu

${ }^{2}$ Division of Invertebrate Zoology, American Museum of Natural History; City College and the Graduate School, City University of New York. e-mail: krishn@amnh.org
} 
the world termite fauna (Krishna and Engel, in prep.), we have gone to great lengths to attend to these nomenclatural difficulties (e.g., Engel and Krishna, 2001a, 2001b, in press a \& b; Engel et al., 2003). In order to bring the usage of family-group names into accord with ICZN (1999) rules, we provide herein a catalog of all such names that have been applied in the Isoptera. This has been done to correct the various circulating errors, to highlight the most egregious problems, and to lay a standardized foundation for the forthcoming catalog. In addition, we have provided systematic descriptions for three subfamilies (two new), which are otherwise not employed by isopterists today but must be validated prior to the publication of the catalog (Krishna and Engel, in prep.). We have also included those published names that are otherwise unavailable at the end of the listing of available names. It must be noted that additional unavailable names have been used on internet sites and employed by GenBank, but none of these have met the criteria of valid publication. While being unavailable, like the three Holmgren names considered below, these names have not been published in the sense defined by the ICZN (1999) (unlike Holmgren's names which were published in accordance with the ICZN) and are therefore excluded from this study.

\section{TAXONOMIC CATALOG}

Below we list in order of priority all family-group names proposed for termites. The names are presented in their original forms, regardless of present day rank or suffix. The type genus is provided along with the correct combining stem for composing a familygroup name. Daggers $(\dagger)$ indicate names proposed for fossil taxa. Some names were believed to have been nomina nuda by Snyder (1949) when they were first proposed; however, prior to 1931 family-group names could be made available by simple formation from an available genus-group name (ICZN, 1999: Art. 12.2.4) and need not have had a formal description.

\section{Available Names}

1. Termitina Latreille, 1802: 293. Type genus: Termes Linnaeus, 1758. Combining stem: Termit-. Note: Latreille (1805, 1810) subsequently changed the name of his "famille" to Termitinae but the name was made available in 1802 (ICZN, 1999: Art. 11.7).

2. Calotermitinae Froggatt, 1897: 516. Type genus: Kalotermes Hagen, 1853 [Calotermes Hagen, 1858 is an unjustified emendation: see Engel and Krishna, 2001a; ICZN, 2002]. Name emended to Kalotermitinae Froggatt, 1897, in accordance with ICZN (1999: Art. 29.1). Combining stem: Kalotermit-.

3. Glyptotermitinae Froggatt, 1897: 518. Type genus: Glyptotermes Froggatt, 1897. Combining stem: Glyptotermit-.

4. Rhinotermitinae Froggatt, 1897: 518. Type genus: Rhinotermes Hagen, 1858. Combining stem: Rhinotermit-.

5. Heterotermitinae Froggatt, 1897: 550. Type genus: Heterotermes Froggatt, 1897. Combining stem: Heterotermit-.

6. Mastotermitinae Desneux, 1904a: 284. Type genus: Mastotermes Froggatt, 1897. Combining stem: Mastotermit-.

7. Hodotermitini Desneux, 1904a: 284. Type genus: Hodotermes Hagen, 1853. Combining stem: Hodotermit-.

8. Stolotermitinae Holmgren, 1910a: 285. Type genus: Stolotermes Hagen, 1858. Combining stem: Stolotermit-. Note: This name unfortunately has priority over Termopsidae Holmgren, 1911, a fact discovered too late to be included in the petition to conserve Termopsis and Termopsidae relative to Mastotermitidae (Engel et al., 2003). Therefore, a second petition was prepared to the ICZN to conserve Termopsidae relative to Stolotermitidae (Engel and Krishna, in press a), since it would be destabilizing for nomenclature to use Stolotermitidae in place of what is today referred to as Termopsidae.

9. Leucotermitinae Holmgren, 1910a: 285. Type genus: Leucotermes Silvestri, 1901. Combining stem: Leucotermit-.

10. Coptotermitinae Holmgren, 1910a: 285. Type genus: Coptotermes Wasmann, 1896. Combining stem: Coptotermit-. Note: Proposed again as new in Holmgren (1910b).

11. Serritermitinae Holmgren, 1910a: 285. Type genus: Serritermes Wasmann, 1897. Combining stem: Serritermit-.

12. Termitogetoninae Holmgren, 1910a: 
286. Type genus: Termitogeton Desneux, 1904b. Combining stem: Termitogeton-.

13. Microcerotermitinae Holmgren, 1910b: 145. Type genus: Microcerotermes Silvestri, 1901. Combining stem: Microcerotermit-.

14. Eutermitinae Holmgren, 1910b: 146. Type genus: Eutermes Heer, 1849. Combining stem: Eutermit-. Note: This name has priority over Nasutitermitinae, despite the synonymy of its type genus with Nasutitermes (ICZN, 1999: Art. 40.1). Eutermes should also take precedence over Nasutitermes, compounding the confusion. Use of Eutermitinae in place of Nasutitermitinae, however, would be destabilizing for termite nomenclature. A petition to the ICZN has been prepared to conserve Nasutitermes and Nasutitermitinae (Engel and Krishna, in press b). Current usage should be maintained until an authoritative decision is rendered.

15. Termopsinae Holmgren, 1911: 35. Type genus: Termopsis Heer, 1849. Combining stem: Termops-. Note: See comments on Stolotermitinae (above).

16. Psammotermitinae Holmgren, 1911: 64. Type genus: Psammotermes Desneux, 1902. Combining stem: Psammotermit-.

17. Pseudomicrotermitinae Holmgren, 1912: 5. Type genus: Pseudomicrotermes Holmgren, 1912. Combining stem: Pseudomicrotermit-.

18. Foraminitermitinae Holmgren, 1912: 5. Type genus: Foraminitermes Holmgren, 1912. Combining stem: Foraminitermit-.

19. Stylotermitinae Holmgren and Holmgren, 1917: 141. Type genus: Stylotermes Holmgren and Holmgren, 1917. Combining stem: Stylotermit-.

20. Arrhinotermitinae Sjöstedt, 1926: 8. Type genus: Arrhinotermes Wasmann, 1902. Combining stem: Arrhinotermit-.

21. Acanthotermitinae Sjöstedt, 1926: 8. Type genus: Acanthotermes Sjöstedt, 1900. Combining stem: Acanthotermit-. Note: This name has priority over Macrotermitinae; however, a petition has been submitted to conserve the usage of Macrotermitinae (Engel and Krishna, 2001b), which has been approved by the ICZN (2003). Macrotermitinae is to be used whenever Macrotermes and Acanthotermes are placed into the same family-group taxon.
22. Macrotermitinae Kemner, 1934: 69. Type genus: Macrotermes Holmgren, 1909. Combining stem: Macrotermit-. Note: See comments for Acanthotermitinae (above).

23. Amitermitinae Kemner, 1934: 110. Type genus: Amitermes Silvestri, 1901. Combining stem: Amitermit-.

24. Miro-capritermitinae Kemner, 1934: 166. Type genus: Mirocapritermes Holmgren, 1914. Combining stem: Mirocapritermit-. Note: Although Kemner (1934) hyphenated the name in its original spelling, the ICZN (1999) does not allow hyphenation and the family-group name must be considered a single word.

25. Nasutitermitinae Hare, 1937. Type genus: Nasutitermes Dudley, 1890. Combining stem: Nasutitermit-. Note: See comments above on Eutermitinae.

26. $†$ Electrotermitinae Emerson, 1942: 10. Type genus: †Electrotermes Rosen, 1913. Combining stem: Electrotermit-.

27. Porotermitinae Emerson, 1942: 10. Type genus: Porotermes Hagen, 1858. Combining stem: Porotermit-.

28. Apicotermitinae Grassé and Noirot, 1954 [1955]: 360. Type genus: Apicotermes Holmgren, 1912. Combining stem: Apicotermit-.

29. Cubitermitini Weidner, 1956: 99. Type genus: Cubitermes Wasmann, 1906. Combining stem: Cubitermit-.

30. Mirotermitini Weidner, 1956: 99. Type genus: Mirotermes Wasmann, 1897. Combining stem: Mirotermit-.

31. Capritermitini Weidner, 1956: 100. Type genus: Capritermes Wasmann, 1897. Combining stem: Capritermit-.

32. Indotermitidae Roonwal and Sen-Sarma In Roonwal, 1958: 81. Type genus: Indotermes Roonwal and Sen-Sarma In Roonwal, 1958. Stem: Indotermit-.

33. †Cretatermitinae Emerson, 1968: 278. Type genus: †Cretatermes Emerson, 1968. Combining stem: Cretatermit-.

34. Prorhinotermitinae Quennedey and Deligne, 1975: 265. Type genus: Prorhinotermes Silvestri, 1909. Combining stem: Prorhinotermit-.

35. †Lutetiatermitinae Schlüter, 1989: 61. Type genus: $\dagger$ Lutetiatermes Schlüter, 1989. Combining stem: Lutetiatermit-.

36. †Carinatermitinae Krishna and Gri- 
maldi, 2000: 134. Type genus: $\uparrow$ Carinatermes Krishna and Grimaldi, 2000. Combining stem: Carinatermit-.

37. †Archeorhinotermitinae Krishna and Grimaldi, 2003: 2. Type genus: $\uparrow$ Archeorhinotermes Krishna and Grimaldi, 2003. Combining stem: Archeorhinotermit-.

38. Syntermitinae Engel and Krishna, herein (see below). Type genus: Syntermes Holmgren, 1909. Combining stem: Syntermit-.

39. Sphaerotermitinae Engel and Krishna, herein (see below). Type genus: Sphaerotermes Holmgren, 1912. Combining stem: Sphaerotermit-.

\section{UNAVAILABLE NAMES}

Some authors (e.g., Banks, 1920; Roonwal and Chhotani, 1989) have erroneously equated the following three names with some of the present families or subfamilies. All three are unavailable and therefore do not enter into zoological nomenclature and should not be used.

1. Metatermitidae Holmgren, 1909: 99. Unavailable, as it was not based on an available genus-group name (ICZN, 1999: Art. 11.7.1.1).

2. Mesotermitidae Holmgren, 1909: 100. Unavailable, as it did not include Mesotermes Haase, 1890 (ICZN, 1999: Art. 11.7.1.1) and was therefore not based on a genusgroup name. Note: This name was proposed as new again in Holmgren (1910a) and Holmgren (1910b). [Mesotermes was an available genus-group name at that time, but recognized by Handlirsch (1906) as a neuropteran and not a termite. Holmgren (1909, 1910a) clearly did not intend this name to be based on the fossil neuropteran Mesotermes but established it instead for a series of explicitly included, living termite genera (see Holmgren, 1910a, 1910b), which he believed to occupy an intermediate phylogenetic position in his scheme of termite relationships; thus, Mesotermes was not included by inference of the generic stem of Mesotermitidae (ICZN, 1999: Art. 11.7.1.1) and the name was never made available.]

3. Protermitidae Holmgren, 1909: 100. Unavailable, as it was not based on an available genus-group name (ICZN, 1999: Art.
11.7.1.1). Note: This name was proposed as new again in Holmgren (1910a) and Holmgren (1910b). [A genus-group name, Protermes, was not proposed until 1910, at which time Holmgren (1910a) did not include Protermes in his Protermitidae, placing it instead in Metatermitidae (in fact, Protermes was never included in Protermitidae). Protermitidae was used exclusively for what Holmgren considered to be the basal termites. Thus, Protermitidae was not subsequently validated in the later publications of Holmgren.]

\section{SYSTEMATIC DESCRIPTIONS}

Below we provide descriptions for three little understood subfamilies of Termitidae, one hitherto little understood and two new. The Foraminitermitinae was originally proposed by Holmgren (1912) but has not been generally recognized. The genera Foraminitermes and Labritermes, however, have increasingly been recognized as distinctive and worthy of exclusion from Termitinae (e.g., Krishna, 1963; Noirot, 2001; Bitsch and Noirot, 2002), where they had been placed. The subfamily is characterized here to make its diagnostic characters more widely understood. Similarly, the mandibulate genera of the nasute termites are excluded from $\mathrm{Na}$ sutitermitinae and a new subfamilial name is required to accommodate this group (proposed as Syntermitinae, below). Lastly, Sphaerotermes is excluded from the Macrotermitinae owing to a unique combination of plesiomorphic and apomorphic traits (see below).

\section{Subfamily ForAminitermitinae Holmgren}

Foraminitermitinae Holmgren, 1912: 5. Type genus: Foraminitermes Holmgren, 1912.

Combining stem: Foraminitermit-.

DiAGNOSIS [Derived from Krishna and Adams (1982)]: Imago. Head densely pilose; fontanelle punctiform, situated at tip of a cornical projection. Forecoxa with longitudinal ridge, without protuberance; tibial spurs 3-2-2. Soldier. Left mandible with upper, inner cutting edge finely serrated, and with blunt teeth appearing as crenulations below serrations; right mandible smooth, without teeth, base of molar region with one or 


\section{TABLE 1}

Hierarchical Outline of Termite Classification

All family-group names indicated; synonymic names italicized.

Order ISOPTERA Brullé, 1832

Family Mastotermitidae Desneux, 1904a

Family Kalotermitidae Froggatt, 1897

$$
\begin{aligned}
& =\text { Glyptotermitinae Froggatt, } 1897 \\
& =\dagger \text { Electrotermitinae Emerson, } 1942
\end{aligned}
$$

Family Hodotermitidae Desneux, 1904a

Subfamily †Carinatermitinae Krishna and Grimaldi, 2000

Subfamily †Lutetiatermitinae Schlüter, 1989

Subfamily Hodotermitinae Desneux, 1904a

Family Termopsidae Holmgren, 1911 ${ }^{\mathrm{a}}$

Subfamily $\uparrow$ Cretatermitinae Emerson, 1968

Subfamily Porotermitinae Emerson, 1942

Subfamily Stolotermitinae Holmgren, 1910a [status: Engel and Krishna, in press] a

Subfamily Termopsinae Holmgren, 1911

Family Rhinotermitidae Froggatt, 1897

Subfamily †Archeorhinotermitinae Krishna and Grimaldi, 2003

Subfamily Coptotermitinae Holmgren, 1910a

= Arrhinotermitinae Sjöstedt, 1926

Subfamily Heterotermitinae Froggatt, 1897

= Leucotermitinae Holmgren, 1910a

Subfamily Prorhinotermitinae Quennedey and Deligne, 1975

Subfamily Psammotermitinae Holmgren, 1911

Subfamily Stylotermitinae Holmgren and Holmgren, 1917

Subfamily Termitogetoninae Holmgren, 1910a

Subfamily Rhinotermitinae Froggatt, 1897

Family Serritermitidae Holmgren, 1910a

Family Termitidae Latreille, 1802

Subfamily Apicotermitinae Grassé and Noirot, 1954 [1955]

= Indotermitidae Roonwal and Sen Sarma in Roonwal, 1958

Subfamily Foraminitermitinae Holmgren, 1912

Subfamily Sphaerotermitinae Engel and Krishna, new subfamily

Subfamily Macrotermitinae Kemner, 1934

= Acanthotermitinae Sjöstedt, 1926 [see ICZN (2003) for priority]

Subfamily Syntermitinae Engel and Krishna, new subfamily

Subfamily Nasutitermitinae Hare, 1937 a

= Eutermitinae Holmgren, $1910 \mathrm{~b}$ [status: Engel and Krishna, in press] ${ }^{\mathrm{a}}$

Subfamily Termitinae Latreille, 1802

= Microcerotermitinae Holmgren, $1910 \mathrm{~b}$

= Pseudomicrotermitinae Holmgren, 1912

= Amitermitinae Kemner, 1934

= Mirocapritermitinae Kemner, 1934

= Cubitermitini Weidner, 1956

= Mirotermitini Weidner, 1956

= Capritermitini Weidner, 1956

$\dagger$ Fossil taxon.

These names have problems of priority associated with them (e.g., Eutermitinae has priority over Nasutitermitinae; Stolotermitinae has priority over Termopsidae), and petitions for conservation of current usage have been made to the ICZN (Engel and Krishna, in press a \& b). Present usage should be maintained until an authoritative opinion is rendered by the ICZN. 
two very tiny, pointed, thornlike spines or projections. Labrum with hyaline tip. Worker. Gut with mixed segment absent; four malpighian tubules separately attached at transverse mesenteron-proctodeum junction, extending forward for short distance and then looping around toward hindgut; malpighian tubules swollen basally; first proctodeal segment $\left(\mathrm{P}_{1}\right)$ tubular and narrow proximally, almost same diameter as midgut, and dilated and saclike distally, with malpighian tubules forming jumbled mass (= pseudomalpighian knot of Noirot, 2001; Bitsch and Noirot, 2002).

INCLUDED GENERA: Foraminitermes Holmgren, 1912 and Labritermes Holmgren, 1914.

COMmENTS: This group was first recognized by Holmgren (1912), who had difficulty placing it with any other group of Termitinae (referring to it also as the "Foraminitermes-reihe") (also recognized as distinctive by other authors; e.g., Krishna, 1963; Krishna and Adams, 1982; Noirot, 2001). Noirot (2001) suggested that Foraminitermes belonged to a new subfamily, while a familygroup name had already been proposed for it nearly a century ago.

\section{SyNTERmitinae, new subfamily}

Type Genus: Syntermes Holmgren, 1909 (not 1910a as cited by Snyder, 1949; Constantino, 1995, 1998; and other authors).

DiAGNOSIS: Imago. Fontanelle generally large, round; slightly depressed or forming a convex plate. Postclypeus moderately or strongly convex, with a median line. Foreand hindwing with short $\mathrm{R}_{1}$, sometimes $R_{2}+R_{3}$ joining costal margin very near the suture. Pronotum with anterior margins projecting laterally into points in Syntermes; in Procornitermes, Cornitermes and Labiotermes anterolateral corners without points, margins even. Arolium absent. Soldier. Nasus (frontal tube) well developed, tip flat; frontal pore wide and conspicuous; well-developed, functioning biting-mandibles; labrum simple, narrow, with hyaline tip. Worker. Gut with mixed segment doubled, dual lobes overlapping the first proctodeal segment $\left(\mathrm{P}_{1}\right)$ (except reduction to single in Procornitermes); enteric valve with spines in the inner scaly membrane (except reduced in Syntermes).

InCLUDED GENERA: Syntermes Holmgren, 1909; Cornitermes Wasmann, 1897; Procornitermes Emerson In Snyder, 1949; and Labiotermes Holmgren, 1912. Other mandibulate genera of Nasutitermitinae may eventually be included here as well.

\section{SPHAEROTERMitinaE, new subfamily}

TyPE GENUS: Sphaerotermes Holmgren, 1912.

Diagnosis: Imago. Head with light, small, punctiform fontanelle. Labrum uniformly sclerotized, transparent; postclypeus with median line. Soldier. Head with sides rounded; inconspicuous fontanelle present in middle of head. Labrum with sides rounded, with hyaline point. Left mandible with a few serrations and blunt tooth near base; right mandible with inner cutting-edge smooth. Pronotum much narrower than head; anterior and lateral margins even, without projecting spines. Worker. Right mandible with 6-7 ridges on molar plate. Labrum uniformly sclerotized (Sands, 1998: lacking the transverse apical band of sclerotization seen in Macrotermitinae, e.g., Donovan et al., 2000); postclypeus strongly convex, with distinct median line. Gizzard with small pulvilli attached posteriorly on columns, crenulated crests of columns I and II poorly developed; setae of pulvilli poorly developed (Noirot, 2001). Conspicuous, backward-oriented bristles at the $\mathrm{P}_{3}-\mathrm{P}_{4}$ (paunch-colon) junction (Noirot, 2001) (unique among the Isoptera).

INCLUDED GENERA: Includes only Sphaerotermes Holmgren, 1912.

COMMENTs: This is a remarkable subfamily sister to the Macrotermitinae (e.g., three nymphal instars, unique worker instar, male workers larger than females) but unlike the macrotermitines, Sphaerotermes is not associated with Termitomyces fungi and lacks the transverse band of sclerotization across the labrum of the worker and the imago (Sands, 1998). While these are indeed plesiomorphies relative to Macrotermitinae, Sphaerotermitinae has some remarkable apomorphic traits that support its recognition [e.g., unique possession of conspicuous, backward-orient- 
ed bristles at the $\mathrm{P}_{3}-\mathrm{P}_{4}$ (paunch-colon) junction: Noirot, 2001].

\section{ACKNOWLEDGMENTS}

We are grateful to Valerie Krishna, David Nickle, and Charles D. Michener for reviews of the manuscript. Support was provided by a National Science Foundation grant to catalog the termites of the world (NSF DEB9870097 to K. Krishna and D. Grimaldi). This is contribution number 3344 of the Division of Entomology, Natural History Museum and Biodiversity Research Center, University of Kansas.

\section{REFERENCES}

Banks, N. 1920. A revision of the Nearctic termites. Bulletin of the United States National Museum 108: 1-85.

Bitsch, C., and C. Noirot. 2002. Gut characters and phylogeny of the higher termites (Isoptera: Termitidae). A cladistic analysis. Annales de la Société Entomologique de France (n.s.) 38(3): 201-210.

Brullé, G.A. 1832. Expédition Scientifique de Morée. Section des Sciences Physiques Zoologie. Deuxième Section-Des Animaux Articulés [vol. 3]. Paris: Levrault, 400 pp.

Chhotani, O.B. 1997. Fauna of India and the Adjoining Countries. Isoptera (Termites), Volume II (Family Termitidae). Calcutta: Zoological Survey of India, xx +800 pp.

Constantino, R. 1995. Revision of the Neotropical termite genus Syntermes Holmgren (Isoptera: Termitidae). University of Kansas Science Bulletin 55(13): 455-518.

Constantino, R. 1998. Catalog of the living termites of the New World (Insecta: Isoptera). Arquivos de Zoologia, São Paulo 35(2): 135-231.

Desneux, J. 1902. Termites du Sahara Algérien recueillis par M. le professeur Lameere. Annales de la Société Entomologique de Belgique 46(10): 436-440.

Desneux, J. 1904a. A propos de la phylogénie des Termitides. Annales de la Société Entomologique de Belgique 48(8): 278-286. [publ. date: 2 September 1904]

Desneux, J. 1904b. Rémarques critiques sur la phylogénie et la division systématique des Termitides (réponse à M. Wasmann). Annales de la Société Entomologique de Belgique 48(10): 372-378. [publ. date: 10 November 1904]

Desneux, J. 1904c. Isoptera, fam. Termitidae. In P. Wytsman (editor), Genera Insectorum [vol.
25]: 1-52. Bruxelles [Brussels]: P. Wytsman. [publ. date: 15 November 1904]

Donovan, S.E., D.T. Jones, W.A. Sands, and P. Eggleton. 2000. Morphological phylogenetics of termites (Isoptera). Biological Journal of the Linnean Society 70: 467-513.

Dudley, P.H. 1890. The termites of the Isthmus of Panama-Part II. Transactions of the New York Academy of Sciences 9: 157-180. [publication date June 1890, not 28 April 1890 as cited by Constantino (2002): results of 5 May 1890 meeting are published on same page as Dudley's article and date on top of facing page is date of previous Academy meeting, not of publication; journal cover indicates an earliest possible publication date of June 1890]

Emerson, A.E. 1942. The relations of a relict South African termite (Isoptera: Hodotermitidae, Stolotermes). American Museum Novitates 1187: 1-12.

Emerson, A.E. 1968 [1967]. Cretaceous insects from Labrador. 3. A new genus and species of termite (Isoptera: Hodotermitidae). Psyche 74(4): 276-289.

Engel, M.S., and K. Krishna. 2001a. Kalotermes Hagen, 1853 (Insecta, Isoptera): proposed designation of Termes flavicollis Fabricius, 1793 as the type species. Bulletin of Zoological Nomenclature 58(2): 100-104.

Engel, M.S., and K. Krishna. 2001b. Macrotermitinae Kemner, 1934 (Insecta, Isoptera): proposed precedence over Acanthotermitinae Sjöstedt, 1926. Bulletin of Zoological Nomenclature 58(3): 206-209.

Engel, M.S., and K. Krishna. 2002. Cryptotermes dudleyi Banks, 1918 (Insecta, Isoptera): proposed precedence over Calotermes (Cryptotermes) jacobsoni Holmgren, 1913. Bulletin of Zoological Nomenclature 59(2): 90-92.

Engel, M.S., and K. Krishna. In press a. Termopsidae Holmgren, 1911 (Insecta, Isoptera): Proposed precedence over Stolotermitinae Holmgren, 1910. Bulletin of Zoological Nomenclature.

Engel, M.S., and K. Krishna. In press b. Nasutitermes Dudley, 1890, Microcerotermes Silvestri, 1901 and Nasutitermitinae Hare, 1937 (Insecta, Isoptera): Proposed conservation. Bulletin of Zoological Nomenclature.

Engel, M.S., K. Krishna, and C. Boyko. 2003. Termopsidae Holmgren, 1911, Termopsis Heer, 1849 and Mirotermes Rosen, 1913 (Insecta, Isoptera): proposed conservation of prevailing usage by the designation of Termopsis bremii Heer, 1849 as the type species of Termopsis. Bulletin of Zoological Nomenclature 60(2): 119-123.

Froggatt, W.W. 1897. Australian Termitidae, Part 
II. Proceedings of the Linnean Society of New South Wales 21(4): 510-552.

Grassé, P.-P., and C. Noirot. 1955 [1954]. Apicotermes arquieri (Isoptère): ses constructions, sa biologie. Considérations générales sur la sousfamille des Apicotermitinae nov. Annales des Sciences Naturelles, Zoologie, série 11, 16(34): 345-388. [publ. date: February 1955]

Haase, E. 1890. Bemerkungen zur Palaeontologie der Insecten. Neues Jahrbuch für Mineralogie, Geologie und Palaeontologie 2: 1-33.

Hagen, H. 1853. Hr. Peters Berichtete über die von ihm gesammelten und von Hrn. Dr. Hermann Hagen bearbeiten Neuropteren aus Mossambique. Bericht über die zur Bekanntmachung geeigneten Verhandlungen der Königlichen Preussischen Akademie der Wissenschaften zu Berlin 18: 479-484.

Hagen, H. 1858. Monographie der Termiten. Linnaea Entomologica 12: 1-342.

Handlirsch, A. 1906. Die fossilen Insekten und die Phylogenie der rezenten Formen. Ein Handbuch für Paläontologen und Zoologen. Leipzig: Engelmann, ix +640 pp.

Hare, L. 1937. Termite phylogeny as evidenced by soldier mandible development. Annals of the Entomological Society of America 37(3): 459-486.

Heer, O. 1849. Die Insektenfauna der Tertiärgebilde von Oeningen und von Radoboj in Croatien. Zweiter Theil: Heuschrecken, Florfliegen, Aderflügler, Schmetterlinge und Fliegen. Leipzig: Engelmann, iv +264 pp.

Holmgren, K., and N. Holmgren. 1917. Report on a collection of termites from India. Memoirs of the Department of Agriculture in India 5: 137171.

Holmgren, N. 1909. Termitenstudien: 1. Anatomische Untersuchungen. Kungliga Svenska Vetenskapsakademiens Handlingar 44(3): 1-215.

Holmgren, N. 1910a. Das System der Termiten. Zoologischer Anzeiger 35(9-10): 284-286. [publ. date: 4 January 1910]

Holmgren, N. 1910b. Isoptera [The Percy Sladen Trust Expedition to the Indian Ocean in 1905 under the leadership of Mr. J. Stanley Gardiner]. Transactions of the Linnean Society of London, series 2, Zoology 14(8): 135-148. [publ. date: November 1910]

Holmgren, N. 1911. Termitenstudien: 2. Systematik der Termiten. Die Familien Mastotermitidae, Protermitidae und Mesotermitidae. Kungliga Svenska Vetenskapsakademiens Handlingar 46(6): 1-86.

Holmgren, N. 1912. Termitenstudien: 3. Systematik der Termiten. Die Familie Metatermitidae. Kungliga Svenska Vetenskapsakademiens Handlingar 48(4): 1-166.
Holmgren, N. 1914. Wissenschaftliche Ergebnisse einer Forschungsreise nach Ostindien, ausgeführt im Auftrage der Kgl. Preuss. Akademie der Wissenschaften zu Berlin von H. v. ButtelReepen. III. Termiten aus Sumatra, Java, Malacca und Ceylon. Gesammelt von Herrn Prof. Dr. v. Buttel-Reepen in den Jarhen 1911-1912. Zoologische Jahrbücher, Abteilung für Systematik, Geographie und Biologie der Tiere 36(2-3): 229-290.

International Commission on Zoological Nomenclature. 1999. International Code of Zoological Nomenclature [Fourth Edition]. London: International Trust for Zoological Nomenclature, xix +306 pp.

International Commission on Zoological Nomenclature. 2002. Opinion 2007: Kalotermes Hagen, 1853 (Insecta, Isoptera): Termes flavicollis Fabricius, 1793 designated as the type species. Bulletin of Zoological Nomenclature 59(3): 209-210.

International Commission on Zoological Nomenclature. 2003. Opinion 2038: Macrotermitinae Kemner, 1934 (Insecta, Isoptera): given precedence over Acanthotermitinae Sjöstedt, 1926. Bulletin of Zoological Nomenclature 60(2): 162-163.

Kemner, N.A. 1934. Systematische und biologische Studien über die Termiten Javas und Celebes'. Kungliga Svenska Vetenskapsakademiens Handlingar 13(4): 1-241.

Krishna, K. 1963. The African genus Foraminitermes Holmgren (Isoptera, Termitidae, Termitinae). American Museum Novitates 2161: 123.

Krishna, K., and C.L. Adams. 1982. The Oriental termite genus Labritermes Holmgren (Isoptera, Termitidae, Termitinae). American Museum Novitates 2735: 1-14.

Krishna, K., and D.[A.] Grimaldi. 2000. A new subfamily, genus, and species of termite (Isoptera) from New Jersey Cretaceous amber. In D. [A.]Grimaldi (editor), Studies on Fossils in Amber, with Particular Reference to the Cretaceous of New Jersey: 133-140. Leiden: Backhuys Publishers, viii +498 pp.

Krishna, K., and D.A. Grimaldi. 2003. The first Cretaceous Rhinotermitidae (Isoptera): a new species, genus, and subfamily in Burmese amber. American Museum Novitates 3390: 1-10.

Latreille, P.A. 1802. Histoire Naturelle, Générale et Particulière des Crustacés et des Insectes [vol. 3]. Paris: Dufart, xii +467 pp.

Latreille, P.A. 1805. Histoire Naturelle, Générale et Particulière des Crustacés et des Insectes [vol. 13]. Paris: Dufart, 432 pp.

Latreille, P.A. 1810. Considérations Générales sur l'ordre Naturel des Animaux composant les 
Classes des Crustacés, des Arachnides, et des Insectes; avec un tableau méthodique de leurs genres, disposés en familles. Paris: F. Schoell, $444 \mathrm{pp}$.

Linnaeus, C. 1758. Systema Naturae per Regna Tria Natura, Secundum Classes, Ordines, Genera, Species, cum Characteribus, Differentiis Synonymis, Locis [10th edition, revised]. Holmiae [Stockholm]: Laurentii Salvii, $824 \mathrm{pp}$.

Noiroit, C. 2001. The gut of termites (Isoptera) comparative anatomy, systematics, phylogeny. II.-Higher termites (Termitidae). Annales de la Société Entomologique de France (n.s.) 37(4): 431-471.

Quennedey, A., and J. Deligne. 1975. L'arme frontale des soldats de termites. I. Rhinotermitidae. Insectes Sociaux 22(3): 243-267.

Roonwal, M.L. 1958. Recent work on termite research in India (1947-57). Transactions of the Bose Research Institute 22: 77-100.

Roonwal, M.L., and O.B. Chhotani. 1989. The Fauna of India and the Adjacent Countries. Isoptera (Termites), Volume 1 (Introduction and Families Termopsidae, Hodotermitidae, Kalotermitidae, Rhinotermitidae, Stylotermitidae and Indotermitidae). Calcutta: Zoological Survey of India, [8] + viii + $672 \mathrm{pp}$.

Rosen, K., von. 1913. Die fossilen Termiten: Eine kurze Zusammenfassung der bis jetzt bekannten Funde. Transactions of the Second International Congress of Entomology, Oxford (1912) 2: 318-335, 6 pls.

Sands, W.A. 1998. The identification of worker castes of termite genera from soils of Africa and the Middle East. Oxon: CAB International, vii +500 pp.

Schlüter, T. 1989. Neue Daten über harzkonservierte Arthropoden aus dem Cenomanium NWFrankreichs. Documenta Naturae, München 56(5): 59-70.

Silvestri, F. 1901. Nota preliminare sui Termitidi sud-americani. Bolletino dei Musei di Zoologia ed Anatomia comparata della Reale Università di Torino 16: 1-8.

Silvestri, F. 1909. Isoptera. In W. Michaelsen and R. Hartmeyer (editors), Die Fauna SüdwestAustraliens. Ergebnisse der Hamburger südwest-australischen Forschungsreise 1905 [vol. 2, pt. 17], pp. 279-314. Jena: Gustav Fischer, $314 \mathrm{pp}$.

Sjöstedt, Y. 1900. Vorläufige Diagnosen einiger afrikanischen Termiten. Entomologisk Tidskrift 20(4): 278.

Sjöstedt, Y. 1926. Revision der Termiten Afrikas: 3. Monographie. Kungliga Svenska Vetenskapsakademiens Handlingar 3(3): 1-419.

Snyder, T.E. 1949. Catalog of the termites (Isoptera) of the world. Smithsonian Miscellaneous Collections 112(3953): 1-490.

Wasmann, E. 1896. Viaggio di Leonardo Fea in Birmania e regioni vicine LXXII. Neue Termitophilen und Termiten aus Indien. I-III. Annali del Museo Civico di Storia Naturale di Genova, serie 2, 16: 613-630.

Wasmann, E. 1897. Termiten von Madagaskar und Ostafrika. Abhandlungen der Senckenbergischen Naturforschenden Gesellschaft 21(1): 137-182.

Wasmann, E. 1902. Termiten, Termitophilen und Myrmekophilen, gesammelt auf Ceylon von Dr. W. Horn 1899, mit anderm ostindischen Material bearbeitet. Zoologischer Jahrbücher, Abteilung für Systematik, Ökologie und Geographie der Tiere 17: 99-164.

Wasmann, E. 1906. Beispiele rezenter Artenbildung bei Ameisengästen und Termitengästen. Biologisches Centralblatt 26(17-18): 565-580.

Weidner, H. 1956. Beiträge zur Kenntnis der Termiten Angolas, hauptsächlich auf Grund der Sammlungen und Beobachtungen von $\mathrm{A}$. de Barros Machado (I. Beitrag). Publicações Culturais da Companhia de Diamantes de Angola 29: 55-106. 


Recent issues of the Novitates may be purchased from the Museum. Lists of back issues of the Novitates and Bulletin published during the last five years are available at World Wide Web site http://library.amnh.org. Or address mail orders to: American Museum of Natural History Library, Central Park West at 79th St., New York, NY 10024. TEL: (212) 769-5545. FAX: (212) 7695009. E-MAIL: scipubs@amnh.org

(2) This paper meets the requirements of ANSI/NISO Z39.48-1992 (Permanence of Paper). 